\title{
A Study on the Evolution of Mao Zedong and Deng Xiaoping's Opening-up Pattern from "One-sided" to "All-Round"
}

\author{
Ying Wang \\ Jilin Agricultural University, Changchun 130118, China
}

\begin{abstract}
Keywords: Mao Zedong, Deng Xiaoping, Marxism-Leninism's theory, opening-up thought
\end{abstract}
\begin{abstract}
Mao Zedong and Deng Xiaoping's thought of opening-up is an important part of Mao Zedong Thought and Deng Xiaoping Theory. It is an inheritance and development of MarxismLeninism's theory of opening-up. It occupies an important position in Mao's Thought and Deng Theory's scientific system, and lays a theoretical basis for opening-up in new time. Through careful study and research for the thought of opening to the outside world, it can be more accurately grasp the theoretical content of Mao's thought and Deng's Theory on the opening-up thought. In addition, it can be more deeply and thoroughly understand the spiritual essence of their thoughts, and then give full play to their guiding effect on the practice of opening-up. In other hand, the learning of this thought has great theoretical and practical significance for further perfecting the scientific system of Mao's Thought and Deng's Theory. It help us to scientifically summarize the historical experience of the opening of the Communist Party of China, and correctly implement the party's opening-up policy. Based on the Marxist standpoint, viewpoint and method, this article summarizes the basis of the forming of two important leaders Mao and Deng's thoughts. It illustrates the importance of opening -up thought for the redemption of development of our country.
\end{abstract}

\section{Introduction}

Opening-up is the common theme faced by all countries in the world today. It is the greatest practice of contemporary China and also is a major subject of academic research. The so-called opening-up refers to a external relations and exchanges of country in the political, economic, cultural and other areas. It also means to face the world and to break the various barriers in world-wide countries, different regions and areas. It will establish extensive contacts with the rest of the world and strengthen international exchanges. At the same time, opening-up can introduce advanced experience, advanced technology achievements and excellent ideological and cultural achievements from other regions and countries. In addition, we can use the advanced equipment and capital of foreign to participate in international market competition in order to strengthen one's own ability to self-reliance, and to develop our own economy. Therefore, the opening-up is relative to the seclusion policy. It is a policy and behavior of sovereign state used in dealing with foreign relations in order to maintain and realize their own national interests [1].

As a basic national policy of the Communist Party of China, the opening-up policy was established after the Third Plenary Session of the 11th CPC Central Committee. But as a thought, it has been a long time. As early as the founding of the Chinese Communist Party, some intellectuals with preliminary communist ideology showed a strong sense of openness. After the founding of the Communist Party of China, they brought this consciousness into the party, so that the Chinese Communist Party began with a distinctive opening feature. Since then, this idea has been further developed and put forward a lot of valuable open thinking. Mao Zedong and Deng Xiaoping are the outstanding representative in this area. The opening-up thought of the Communist Party of China is mainly embodied and expressed by Mao and Deng's thoughts. They are the main makers and executor for China's opening-up strategy and policy [2-4]. 


\section{The main basis of the formation of Mao and Deng's opening-up thought}

Engels pointed out that the theoretical thinking of each age is a product of history, and it has different forms in different times, and thus it has very different content. The opening-up thought proposed by Mao Zedong Deng Xiaoping, as a kind of historical thinking, it is also a kind of historical product. They formed with profound theoretical basis and historical basis and realistic basis.

(1). Theoretical basis: They all absorb and learn the opening-up theory from Marxism-Leninism

After painstaking research for capitalist society, Marx and Engels concluded that: the future society should be a open society, and the material production is not a single, but a socialized mass production interdependently. Mao and Deng applied the opening-up theory of Marxist-Leninist into China. Combined with China's concrete practice, it forms a opening-up thought with Chinese characteristics. The thought not only shine the glory of Marxism-Leninism, but also add new content for the treasure house of Marxist-Leninist theory [5-8].

(2). Historical basis: They all inherit the opening-up thought from modern Chinese enlightened people and take painful lessons from the closed-door policy in modern China.

There are a lot of economic and cultural exchanges with foreign countries in history, but in the past, China is not an open country. The self-sufficiency natural economy play a dominant role in feudal society. So in this condition, China cannot become a opening-up society. After the Opium War, China gradually reduced to semi-colonial and semi-feudal society. in order to save the Chinese nation's peril, a group of advanced Chinese people advocated opening eyes to the world and learning from Western countries.

When we look back through history, we can see that Chinese people paid a painful price due to the closed-door policy in the past few years, which cause China's long-term economic development in a state of backwardness. Deng Xiaoping and other central leaders have carefully summed up this lesson, and he said: "Now any country need to be developed, retreat is impossible."

We have summed up the historical experience and realized that self-seclusion is an important reason for hindering Chinese economic development. Experience shows that is not successful to development economy closing the door, and China's development is inseparable from the world. If China want to seek development and get rid of poverty and backwardness, it must be open.

(3). Realistic basis: They are closely integrated with the objective reality of Chinese revolution and construction.

Mao said: "Any thought, if it cannot connect with the objective of the actual things, and if there is no objective need. If it not serve the people, then it does not work. Even it is the best things or is Marxism-Leninism."[9]. The opening-up thought proposed by Mao and Deng is the objective needs that benefits the development of Chinese society. The thought is produced according to the urgent needs of the Chinese revolution and construction.

In summary, Mao and Deng have a common recognition in the opening-up thought. Their thoughts absorb and learn from the opening-up theory from the proletarian revolutionary mentor such as Marx, Engels, Lenin and Stalin. And the thought inherit the opening-up theory from modern Chinese enlightened people, especially Sun Yat-sen's thought. They take warning from modern China's closed-door experience, and closely combine the objective reality of the Chinese revolution and construction.

\section{Open pattern from "one-sided" to "all-round"}

(1) The "one-sided" strategy

The "one-sided" strategy is the first foreign strategy after the founding of new China. It was developed and implemented by the first leadership of the Communist Party of China. At the moment, the situation both at home and board is complicated and violent, and it has a strong characteristics of the times. From a general perspective, its formulation and implementation conforms to the prevailing international context and, and also lines with China's interests and goals. On the whole, it is a successful strategy. 


\section{(2) The "all-round" strategy}

From the late 1970s to the early 1980s, with the changes of international situation, Chinese leaders have a new understanding for the issue of war. The Third Plenary Session of the Eleventh Central Committee of the Communist Party of China (CPC) decided that the party's strategic focus should be shifted to economic construction. They confirmed the major policy of reform and opening up. At the same time, Sino-American relations encountered obstacles on the Taiwan issue. The Sino-Soviet relations begun to loosen. In these profound changes, China changed the "one line" strategy and pursues an independent foreign policy. We take the nonalignment policy with different countries and carry out all-round diplomacy.

Review the change of diplomatic strategy, we can see that some new leaders of China scientifically analyze the domestic and international situation by using Marxist theory. They size up the situation and plan strategies. They also can firmly grasp the overall situation in the process of the formulation and adjustment of China's diplomatic strategy. After suffering the change of international relations, their strategy have made brilliant achievements. In the late 1980s, the world entered the old and new patterns of alternating times. The third generation of the central leadership, taking Jiang Zemin as the core, it creatively inherit and develop Deng Xiaoping's diplomatic thinking, so that China's diplomacy has made new achievements. Since the beginning of the 21 st century, Hu Jintao as the general secretary of the Party Central Committee calmly analyze the situation at home and abroad, and firmly grasp the strategic opportunity. They hold high the banner of peace, development and cooperation. So that China's foreign work has made new and significant progress.

The pattern of opening-up is a regional distribution with opening economy, and it is also the developing composition of economic development structure and degree based on the needs of domestic economic development and the international economic environment conditions. Under the transition period from the revolutionary war era to the socialist construction in China, Mao proposed different foreign policy. He also made a pioneering contribution to the development of the foreign-related business in the new period based on the different domestic and international situation in different periods. Deng Xiaoping inherit the opening-up cause of Mao, and develop it in a new way, ran out of China's new image of opening up. He created a set of theories of opening to the outside world with socialism with Chinese characteristics and opened up a new situation of all-round, multi-level and wide-ranging areas that opened up to the outside world, and brought about a new prosperity in China's opening-up cause.

\section{Enlightenment and thinking}

Mao is the explorer of the opening-up thought in China's socialist construction, and Deng is the founder and practitioner of the opening-up theory in socialism with Chinese characteristics. There are many similarities between the two of their thought, whether is the source of theory, or the recognition on the needs, the content, the principles and other issues of opening-up.

At the same time, their opening-up thought have many differences in theory and practice. The reason is that they live in a different time with different historical conditions, and they accumulate different kinds of experience. In addition, some personal and social factors also can influence them, and give them great effects. It can be said that a variety of factors have led to the historical limitations of Mao's opening-up thought. Of course, Mao is a normal human, so he cannot develop beyond the limitations of history and the times. At the moment, China had just come out of the troubled situation. In the short term, it was impossible for China to analyze and view the opening-up from the internal relations of the world economy and the inherent requirements of the socialist commodity economy. In addition, we have a poor experience in socialist construction, so the limitation is unavoidable. However, with the development of history, this limitation is gradually overcome. Mao's exploration provides valuable lessons for the blueprint of Deng 's reform and opening-up. Deng corrected the deviation of Mao's deviation of conception, and break through the limitations of Mao's thinking on opening -up. He regard the opening-up problem from the world's overall and the relationship, and 
connect the opening-up and the strategic objectives of China's economic development. He put the opening -up as the basic national policy and seriously put into practice, which push China's opening-up to a new stage. Through the theoretical study for the two ideas, we draw the following conclusions:

(A) The opening-up must start from the world's integrity, inter-connectedness and realize the contemporary capitalism.correctly.

(B) The opening-up must be proceeded in political, economic, science and technology, culture and so on.

(C) The opening-up is not only "introduced", but also "going out", and expand the channels in many aspects.

(D) The opening-up must carry forward the spirit of progressing with the times and strive to improve the level of opening-up.

\section{Conclusion}

Under the correct guidance of Marxist ideology, and based on the inheritance of Mao's opening-up thought, Deng Xiaoping comprehensively develop and highly promote the level of opening-up with great theoretical courage and practical courage. This measure not only enrich and develop the opening-up theory of Marxist-Leninist, but also provide the correct theoretical guide for the practice of opening-up of socialist countries. Under the correct guidance of generations of leaders, China's opening -up has achieved fruitful results. The opening-up thought quickens the process of China's economic integrating into the global economic integration, which has effectively promoted the development of China's national economy, and strengthened China's comprehensive national strength as well as improved China's position in the international economy. The practice of China for more than 50 years shows that opening-up is the only way to promote China's economic development. Although there are some problems in the introduction of foreign capital and the implementation of opening-up policy, it is not realistic to solve the all problems and avoid all the unfavorable element. We believe that the opening-up theory of the Communist Party of China is constantly developing under the new situation of world multipolarization and economic globalization. And under the correct leadership of the new generation of leading collectives, we will be able to keep pace with the times and blaze new trails in a pioneering spirit. At the same time, China's opening-up will strive for further improvement in future.

\section{References}

[1]. Huang Yasheng. Capitalism with Chinese Characteristics (New York: Cambridge University Press, 2008), p.50-108.

[2]. Mao Zedong, "Reading Notes on the Soviet Text Political Economy (1961-1962)," in A Critique of Soviet Economics (New York: Monthly Review Press, 1977), p.87-88.

[3]. K. Wittfogel, 'The Legend of Maoism' in China Quarterly (CQ), nos 1 and 2 (January-March and April-June 1960) p. 72-86 and 16-34.

[4]. S. Schram, 'The Marxist' in D. Wilson (ed.), Mao Tse-tung in the Scales of History (Cambridge University Press, 1977), p. 67.

[5]. A. Walder, 'Marxism, Maoism and Social Change' in Modern China, vol. 3, nos 1 and 2 (January and April 1977), p.101-16 and 125-60.

[6]. S. Schram, 'The Marxist' in D. Wilson (ed.), Mao Tse-tung in the Scales of History, p.35.

[7]. Mao Zedong, Some Questions Concerning Methods of Leadership in Selected Works, vol.3, p.119.

[8]. Yao Wenyuan, 'On the Social Basis of the Lin Piao Anti-Party Clique' in PR, no. 10 (1975), p. 6.

[9]. Mao Zedong, 'On the Correct Handling of Contradictions Among the People' in Selected Works, vol. 5 , p. 397. 